http://dx.doi.org/10.18778/8088-239-3.21

ŁUKASZ MiKoŁaJ SADowsKi

Akademia Sztuk Pięknych

im. Władysława Strzemińskiego w Łodzi

\title{
O ARCHITEKTURZE EUROPEJSKIEJ W MALAKCE
}

$M$ alezyjska Malakka (ang. Malacca, mal. Melaka) to jeden z najciekawszych architektonicznie i kulturowo ośrodków miejskich na Dalekim Wschodzie. Egzotyczna nazwa przywodzi na myśl dawne szlaki handlowe, którymi sprowadzano bogactwa Orientu. Egzotyki jednak (przynajmniej w centralnej, historycznej części miasta) jest tam mniej, niż można by się spodziewać. Dawna malajska osada przez pięć stuleci znajdowała się bowiem we władaniu Europejczyków. Miasto, gdzie wymieszały się nie tylko style architektoniczne, ale także rasy, religie czy kuchnie różnych narodów. Specyfikę miejsca i jego unikalność doceniło UNESCO, wpisując w 2008 r. (wraz z Georgetown) Malakkę na listę światowego dziedzictwa ${ }^{1}$. Miało to oczywiście przemożny wpływ na ochronę zabytków oraz rozwój turystyki.

Tekst poniższy jest zmodyfikowaną wersją referatu zaprezentowanego przeze mnie w Warszawie w listopadzie 2014 r. Dotyczył on wartości niematerialnych w sztuce, architektura stanowiła wprowadzenie do zagadnień dotyczących folkloru, języka, kuchni. W tym tekście pragnąłbym skupić się raczej na rozwoju historycznym miasta i przedstawieniu pokrótce jego kolonialnych zabytków architektonicznych, które powstawały tu od początków XVI w. do połowy wieku XX.

Nazwy wymieniane w tekście podane zostały w transkrypcji polskiej, stąd też: Malakka, a nie: Melaka czy Malacca, podobnie jak: Macao, a nie: Macau. Z uwagi na niewielką liczbę publikowanych opracowań na temat historii i kultury miasta wspierałem się licznymi artykułami z sieci, które w znacznym stopniu wypełniają obecnie tę lukę.

Dzisiejsza Malakka to stolica stanu o tej samej nazwie, położonego na południu Półwyspu Malajskiego. Od wieków region ten odgrywał niezwykłą rolę w komunikacji i handlu. Cieśnina Malakka oddzielająca Malaje od

1 Obiekty z listy światowego dziedzictwa Unesco, http://pl.wikipedia.org/wiki/Obiekty_z_ listy_dziedzictwa_UNESCO_w_Azji\#Malezja_.284.29 (dostęp: 01.09.2014). 
Sumatry jest jednym z najważniejszych szlaków handlowych łączących akweny Oceanu Indyjskiego i Spokojnego. Samo miasto powstało dość późno - około 1400 r., należy jednak pamiętać, że w okolicach istniały już wcześniej ośrodki miejskie, porty, z których najbardziej znany to Singapura (Singapur), w XIX w. podniesiony przez Brytyjczyków do rangi jednego z najważniejszych portów świata ${ }^{2}$. I to właśnie radża Singapuru Iskander Szach (Parameswara), zmuszony do ucieczki na wskutek najazdu Madżapahitów, założył na przełomie XIV i XV w. nową osadę ${ }^{3}$. Powstała on u ujścia rzeki Bertam (obecnie Melaka), w jednym z najwęższych miejsc cieśniny. W ciągu stulecia znalazła się wśród najbardziej istotnych ośrodków handlowych regionu - stała się stolicą sułtanatu, portem, do którego przybywali kupcy z krajów arabskich, Indii, Chin i Japonii. Sześciokrotnie odwiedzał ją także słynny chiński admirał Zheng He. Około 1500 r. sułtanat osiągnął swe apogeum polityczne i gospodarcze, powiększając terytorium, obejmujące na początku XVI w. zarówno tereny położone na Półwyspie Malajskim, jak i na Sumatrze ${ }^{4}$. Z dawnej zabudowy miasta nic się nie zachowało. Była ona zapewne z drewna - najpowszechniej stosowanego budulca na Malajach.

Bogactwo i znaczenie miasta budziło zainteresowanie Portugalczyków. Bardzo szybko po dotarciu do Indii przez Vasco da Gamę (1499) rozpoczęli oni intensywną ekspansję kolonialną. Z uwagi na brak ludzi nie mogła ona mieć charakteru podboju i okupacji rozległych terytoriów. Portugalczycy byli wyłącznie zainteresowani zdominowaniem ważnych strategicznie miejsc na szlakach handlowych. Po ich opanowaniu, ufortyfikowaniu i rozbudowie infrastruktury mieli zapewnioną kontrolę najważniejszych dróg morskich - i niejednokrotnie lądowych. Stad też faktorie i kolonie portugalskie były pojedynczymi punktami rozsianymi na mapie świata (Mozambik, Ormuz, Bahrajn, Goa, Macao, Timor i wiele innych...). Malakka z racji swego atrakcyjnego położenia i bogactw stała się naturalnym celem ekspansji portugalskiej. Inspiratorem i wykonawcą planu był drugi wicekról Indii (Estado da India) Afonso da Albuquerque. Po zdobyciu i umocnieniu Goa w Indiach (1510) opanował w 1511 r. Malakkę5. Dzięki temu możliwa stała się dalsza ekspansja w kierunku Chin (gdzie jako pierwszy dotarł Jorge Alvares, już w 1513 r.), założenie faktorii w Macao (1557) i w japońskim Nagasaki $(1542)^{6}$.

\footnotetext{
${ }^{2}$ L. Kip Lin, The Singapore House 1819-1942, Singapore 1995, s. 53-55.

3 Por. hasło „Parameswara sultan”, http://e.wikipedia.org/wiki/Parameswara_sultan (dostęp: 01.09.2014).

4 Por. hasło „Malacca sultanate”, http://en.wikipedia.org/wiki/Malacca_sultanate (dostęp: 01.09.2014).

${ }^{5}$ A. Wyczański, Historia powszechna. Wiek XVI, Warszawa 1999, s. 37.

${ }^{6}$ L.R. Wank-Nolasco, History of Macau, Macau 1998, s. 9-11; A. Wyczański, op. cit., s. 37.
} 
Malakka została bardzo szybko ufortyfikowana. Portugalczycy zgodnie ze swoimi zwyczajami wpierw zabezpieczyli osadę militarnie. Wznieśli oni pierwszy fort (primitiva Fortaleza), którego plan z 1511 r. (w wersji skopiowanej w roku 1610) zachował się w zbiorach Biblioteki Królewskiej w Brukseli. Budowla położona na wzgórzu, u ujścia rzeki do morza, to prostokąt murów $\mathrm{z}$ dominującą wieżą. Wzniesiono ją zapewne w bardzo szybkim tempie, jest bowiem widoczna na cyklu rysunków Gaspara Correi z ok. 1529 r. ${ }^{7}$ Na kolejnych rysunkach z 1604 r. widać rozbudowę fortyfikacji bastionowych, obejmujących swym zasięgiem całą osadę europejską. W porównaniu z lokalną, drewnianą zabudową były one solidnym gwarantem bezpieczeństwa miasta i fortecy. Sama osada rozwinęła się wokół „fortalezzy”, na wschód od ujścia rzeki Malakka ${ }^{8}$. Fortyfikacje nosiły nazwę „A Famosa”. Do naszych czasów zachowały się fragmentarycznie i nazwą tą obejmuje się dziś relikty na wzgórzu i dookoła niego. Najbardziej znanym obiektem, który przetrwał XIX-wieczne wyburzenia jest brama Świętego Jakuba (Porta de Santiago).

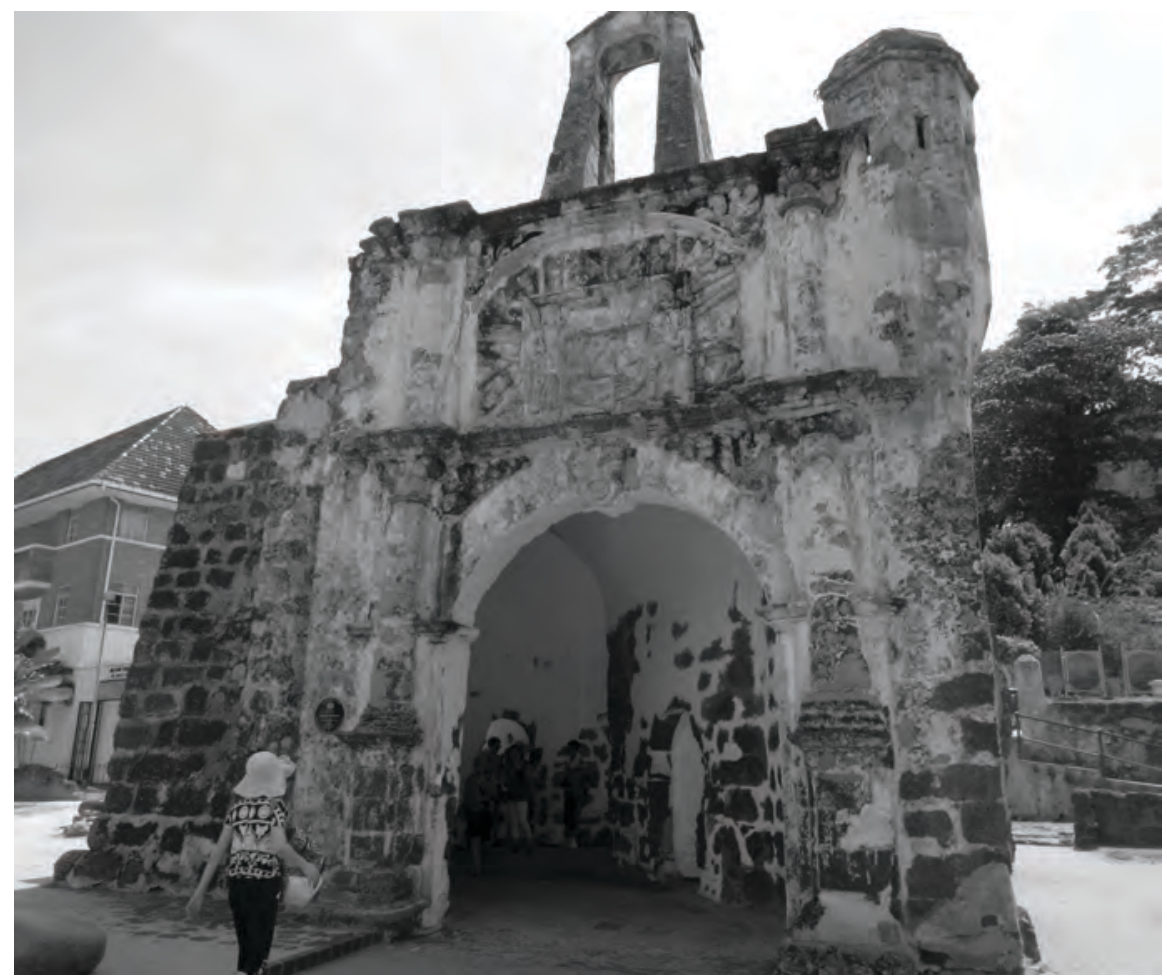

Ryc. 52. Porta de Santiago, Malakka, 2014

${ }^{7}$ Oba rysunki (plan i widok miasta) reprodukuje Pedro Dias, por. idem, Historia Da Arte Portuguesa No Mundo (1415-1822). O Espaco do Indico, Navarra 1998, s. 402.

${ }^{8}$ Ibidem, s. 403. 
W ostatnich latach odsłonięte i zabezpieczone zostały pozostałości obszernych partii murów kurtyn i bastionów. Na przeciwległym, zachodnim brzegu rzeki istniała większa osada, zamieszkała przez ludność azjatycką - głównie malajską, chińską. Wiadomo, że oprócz głównej części ufortyfikowanej, w której chroniła się ludność w czasie zagrożeń, istniały przedmieścia: Tranqueira, Yler, Tajonpaser i Saba'.

Portugalczycy raczej przejęli istniejący wcześniej niż zorganizowali nowy handel. Do Europy ekspediowano:

przede wszystkim korzenie, jak pieprz, cynamon, gałka i kwiat muszkatołowy, szafran, kminek, imbir, anyż, koper i inne produkty Malajów. Do korzeni dochodziły takie artykuły roślinne, jak kawa, pistacja, daktyle, cytryny, herbata. Handlowano również kruszcami szlachetnymi z Sumatry (złoto, srebro i wyroby z nich), żelazem, ołowiem, cyną, dy wanami i jedwabnymi tkaninami [...], perłami z Persji, perfumami z Arabii oraz koszenilą, suszonymi owocami i rzadkimi gatunkami drewna, laką, werniksem, bursztynem, kością słoniową, indygo i cukrem. W zamian za te produkty wysp Archipelagu Malajskiego i Azji z Europy przywożono sukno z Flandrii, Włoch i Hiszpanii, jedwabie z Neapolu i Florencji, zwierciadła z Wenecji, poza tym oliwę, płótno, miedź, cynober, kruszce itd. ${ }^{10}$

Malakka stała się jednym z najważniejszych punktów handlu światowego, centrów wymiany towarów między różnymi kręgami cywilizacyjnymi.

Port tamtejszy posiadał tę nieocenioną zaletę, że okręty mogły o każdej porze do niego wpływać lub go opuszczać. Ale niektóre i tutaj bywały zmuszone do dłuższego wyczekiwania. Kto z Chin lub Japonii nie trafi tu przed Wielkanocą, musi odczekać następny okres monsunu. Z Indii przybywają tutaj okręty dwa razy, w maju lub wrześniu; natomiast do Indii można płynąć tylko w jednym okresie pogody [podkreślenie w oryginale - Ł.M.S]. Z tego powodu Malakka była odpowiednim portem przeładunkowym dla towarów z Chin, Japonii i Moluków z jednej strony, a produktów Arabii, Indii i Europy z drugiej ${ }^{11}$.

Oprócz znaczenia handlowego miasto odgrywało bardzo ważną rolę w komunikacji. Ktokolwiek płynął z Europy na Daleki Wschód lub w przeciwnym kierunku, musiał przepływać przez Malakkę. Już w połowie XVI w. stała się ona jedną z „baz” misjonarzy europejskich - zwłaszcza jezuitów. Franciszek Ksawery przebywał tutaj trzykrotnie w drodze do Japonii i Chin

9 Por. hasło „Portugeuse Malacca”, http://en.wikipedia.org/wiki/Portuguese_Malacca (dostęp: 04.09.2014).

${ }_{10}$ A. Wyczański, op. cit., s. 37-38.

11 F.A. Plattner, Gdy Europa szukała Azji, Kraków 1975, s. 64. 
(1546, 1549 i 1552). Tutaj też zostało według przekazów przewiezione z chińskiej wyspy Sancian (Shangchuan) i pochowane tymczasowo, na okres dziewięciu miesięcy, jego ciało. Potem przewieziono je do Goa ${ }^{12}$. Około $1556 \mathrm{r}$. jezuici zorganizowali siedzibę dla prokuratora zakonnego. Jego zadaniem było zaopatrywanie współbraci w Japonii i na Molukach „we wszystko, co potrzebne, i od czasu do czasu posyłać wiadomości do Goa"13. Z biegiem czasu ta skromna instytucja rozwinęła się w kolegium, gdzie nauczano dzieci portugalskie, oraz miejsce zamieszkania misjonarzy w trakcie ich pobytu w porcie.

Związki misjonarzy (szczególnie jezuickich) z Portugalią były bardzo silne. Żaden z nich nie mógł płynąć na Wschód bez zgody władz, korzystali oni w podróży z okrętów portugalskich. Pomoc, którą otrzymywali od zarządzających koloniami, była poważna, ale z drugiej strony misjonarze byli zobowiązani popierać portugalskich kupców i gubernatorów we wszelkich sporach z miejscowymi władzami. Przez to często tubylcy identyfikowali katolicyzm jako religię „portugalską” ${ }^{14}$.

Najważniejsza świątynia katolicka w mieście, kościół Matki Bożej na Wzgórzu (Nossa Senhora do Monte), została podarowana jezuitom przez biskupa Goa w 1548 lub 1549 r. Ten kościół, którego świetnie zachowane ruiny dominują do dziś nad historyczną częścią miasta, znajdował się w centrum portugalskiej fortecy-miasta. Pierwszy budynek został wzniesiony przez Duarte Coelho w 1521 r. $^{15}$

Istniejąca kamienna struktura to prosta, jednonawowa, dwukondygnacyjna konstrukcja, nakryta pierwotnie dwuspadowym dachem. W $1590 \mathrm{r}$. została do niej dostawiona dzwonnica. Pozbawiona dekoracji rzeźbiarskiej budowla jest obecnie czymś w rodzaju lapidarium, gdzie zgromadzono liczne płyty nagrobne. Pochodzą one jednak już z czasów holenderskich - następnej epoki w dziejach miasta.

Wzrost znaczenia Holandii oraz jej ekspansja kolonialna spowodowały chęć zagarnięcia posiadłości portugalskich. Pierwsza połowa XVII w. to okres silnej rywalizacji, w czasie której Holendrzy oblegali lub zajmowali miasta i terytoria należące do przeciwnika. Część z nich obroniła się (Macao), inne zostały odbite po kilku dekadach (Brazylia). Do dotkliwych strat Portugalii należy na pewno zaliczyć utratę Cejlonu i Malakki. Ta ostatnia została zajęta po nieudanych wcześniejszych próbach przez oddziały Holenderskiej

${ }^{12}$ Ch. Hollis, Historia jezuitów, Warszawa 1974, s. 43. Obecnym miejscem pochówku św. Franciszka Ksawerego jest Goa (bazylika Bom Jesus). Prawe ramię umieszczono w XVII w. w relikwiarzu w rzymskim kościele Il Gesù. Niemniej zarówno w Makao, jak i Malakce pokazywane są puste groby, w których miało być złożone ciało misjonarza przed wysłaniem go do Goa.

${ }^{13}$ F.A. Plattner, op. cit., s. 64.

${ }^{14}$ Ch. Hollis, op. cit., s. 69.

15 P. Dias, op. cit., s. 405. 
Kompanii Wschodnioindyjskiej (Vereenigde Oostindische Compagnie, VOC) w roku 1641.

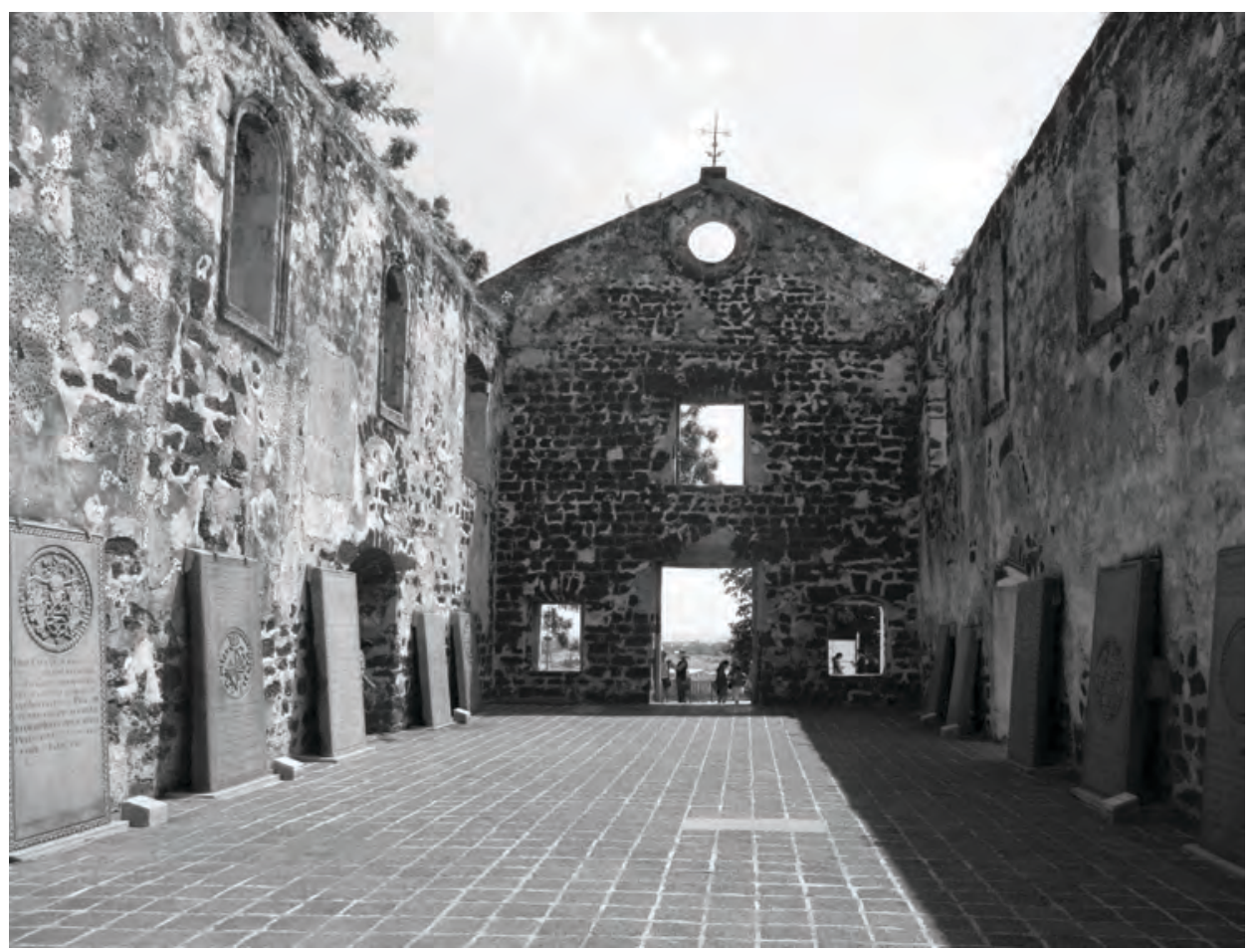

Ryc. 53. Wnętrze dawnego kościoła jezuickiego z widocznymi holenderskimi płytami nagrobnymi, Malakka, 2014

Niderlandzkie rządy pociągnęły za sobą obniżenie rangi miasta. Malakka pozostawała na uboczu ich zainteresowań - głównym dominium były posiadłości na Jawie i rozbudowywana wówczas stolica kolonii - Batawia, czyli dzisiejsza Dżakarta. Co ciekawe, jeden z lokalnych władców jawajskich określił nowo powstałe miasto właśnie jako „Nową Malakkę"16. Mimo długiego, trwającego blisko 183 lata (1641-1825) okresu panowania na Malajach, Holendrzy zdecydowanie bardziej dbali o rozwój Jawy. Inwestycje nowych władców w Malakkce obejmowały dalszą rozbudowę fortyfikacji, również poza miastem (fort św. Jana). Bastiony zostały wzmocnione, ich dawne nazwy zastąpiono nowymi (np. St. Domingo - Amsterdam, Madre Deus - Emelia, Santiago - Wilhelmus itp. ${ }^{17}$. Stworzone zostało także nowe administracyjno-religijne centrum miasta. Dawna świątynia jezuicka została przejęta

${ }^{16}$ C.R. Boxer, Morskie Imperium Holandii 1600-1800, Gdańsk 1980, s. 196.

17 Z. Majid, Bastion Middelburgh, bmw., bdw. 
przez holenderski kościół reformowany. Zmieniono wezwanie z Matki Bożej na św. Pawła. Krypta oraz teren wzgórza stały się największym cmentarzem dla Europejczyków (zwłoki chowano tam już od czasów portugalskich). W 1753 r. ukończono i konsekrowano nowy Bovenkerk, (obecnie anglikański Christ's Church), który zastąpił starą strukturę na wzgórzu.

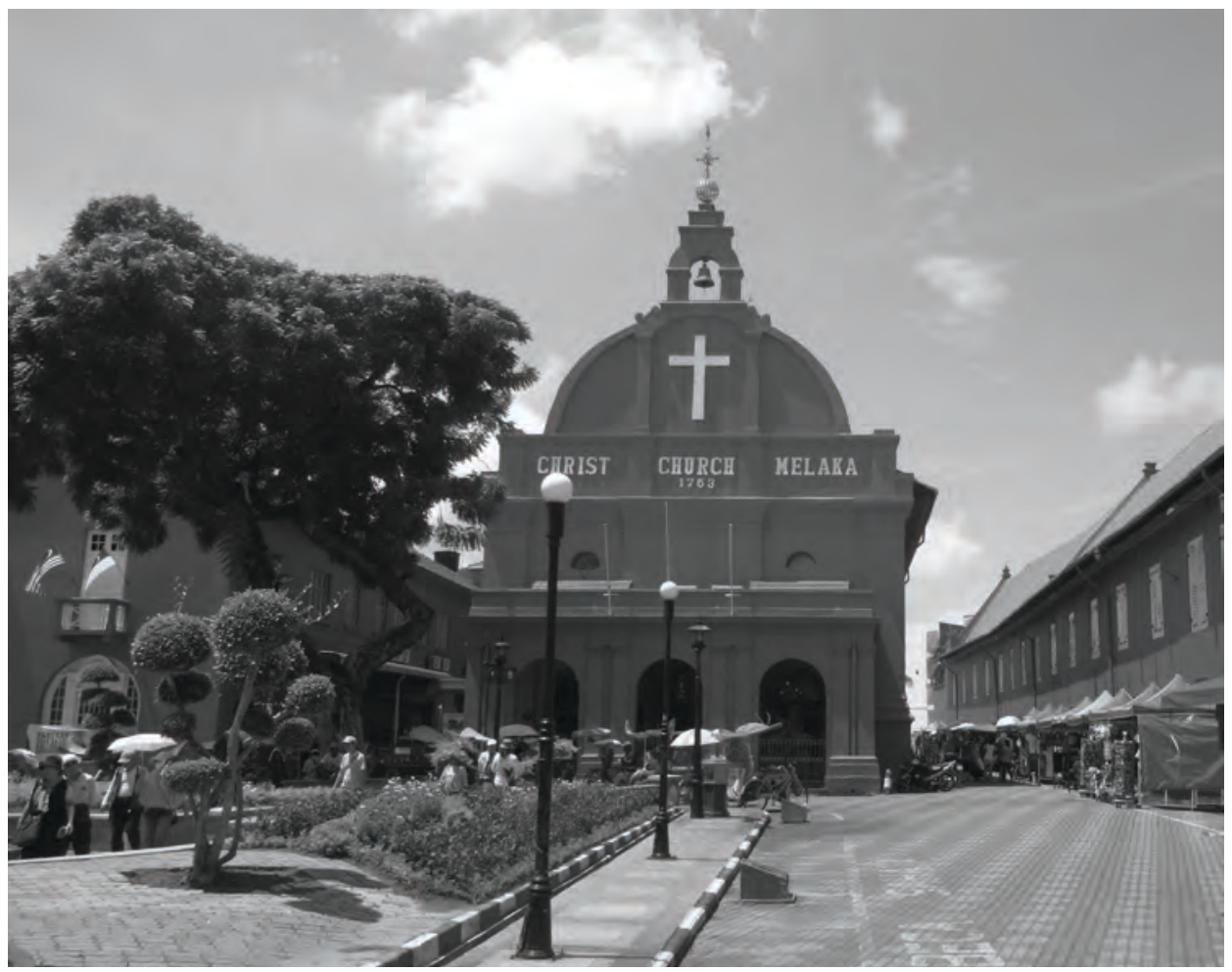

Ryc. 54. Bovenkerk, obecnie Christ's Church, Malakka, 2014

Nowy kościół wybudowany został poniżej, nad brzegiem rzeki, obok ratusza. Powstał dzięki temu plac, pełniący odtąd, jak już wspomniano, rolę centrum kolonialnego miasta. Z jednej strony zachodnie zbocze wzgórza i wschodnią pierzeję placu zajął malowniczo wkomponowany w teren, wzniesiony w 1650 r. Stadthuis.

Był on siedzibą i biurem gubernatora oraz jego zastępcy. Z drugiej strony, od północy, plac zamykał kościół o prostej, urozmaiconej fasadzie, zakrywającej asymetryczny, holenderski dach (Dutch Gambrel) ${ }^{18}$.

18 Por. hasło „Christ Church”, http://en.wikipedia.org/wiki/Christ_Church_Malacca (dostęp: 06.09.2014); por. hasło „Dutch Malacca”, http://en.wikipedia.org/wiki/Dutch_Malacca (dostęp: 06.09.2014). 


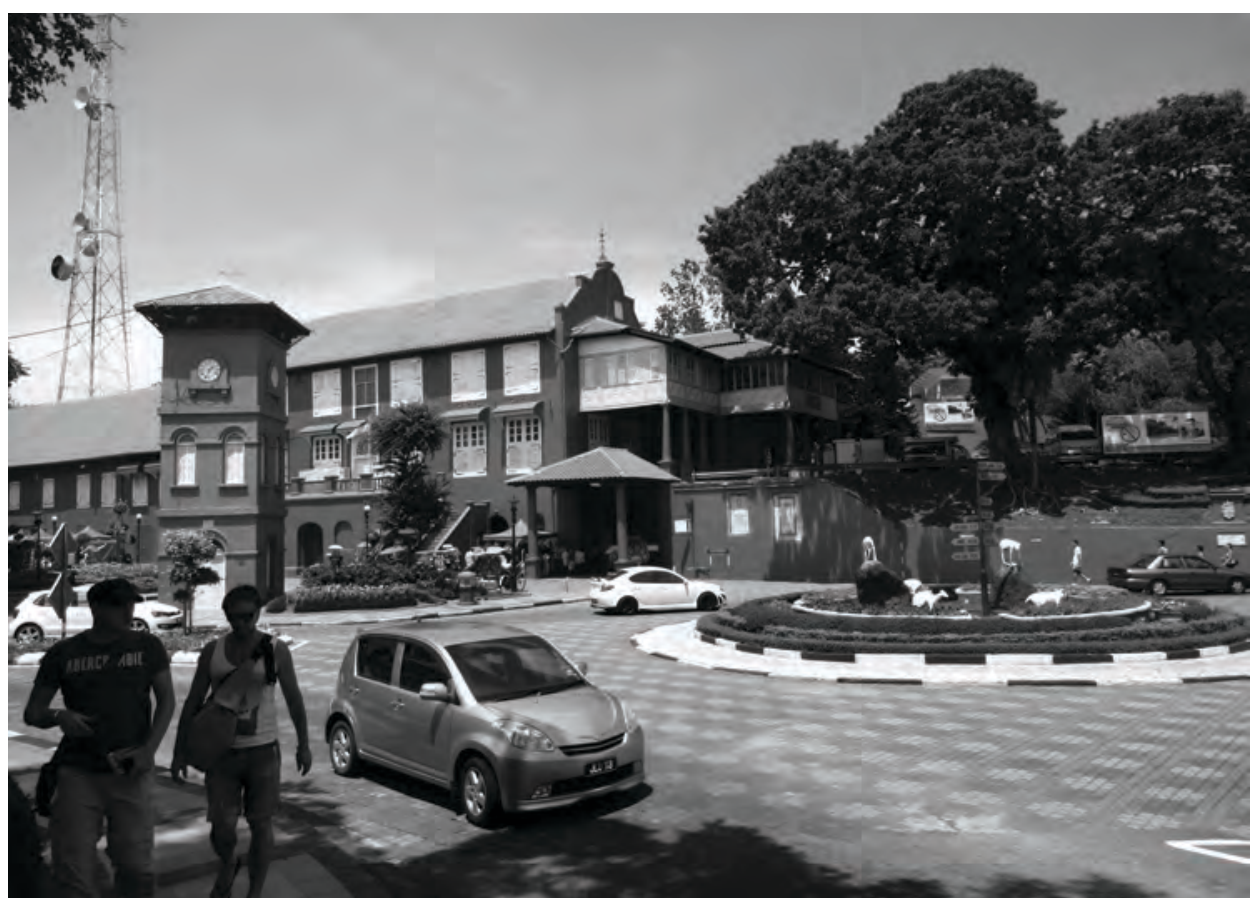

Ryc. 55. Stadthuis, Malakka, 2014

Co ciekawe, Holendrzy tolerowali istnienie meczetów oraz świątyń chińskich czy hinduistycznych, nie zezwalali jednak na budowę kościołów katolickich, bojąc się „atrakcyjności” liturgii rzymskiej wobec ich własnych praktyk. Obrządek rzymski dużo silniej przyciągał miejscową ludność - choćby ze względu na bogactwo dekoracji - kontrastując z prostotą wystroju protestanckiego ${ }^{19}$. Nabożeństwa zostały zakazane, a szczególnie zabraniano wstępu jezuitom, którzy mimo to w ukryciu próbowali potajemnie docierać do współwyznawców ${ }^{20}$. Dopiero w roku 1710 pozwolono katolikom wznieść na obrzeżach miasta własną świątynię. Kościół św. Piotra (tzw. portugalski) jest obecnie najstarszą istniejącą świątynią katolicką na Malajach $^{21}$. Prezentuje on formy późnego baroku, mocno uproszczonego, zapewne z uwagi na skromność środków oraz ograniczenia wprowadzane przez Holendrów.

Formalnie Malaje należały do Holandii do 1825 r., w rzeczywistości zostały jednak zagarnięte i okupowane przez Brytyjczyków w latach

${ }^{19}$ C.R. Boxer, op. cit., s. 148-149.

${ }^{20}$ F.A. Plattner, op. cit., s. 65.

${ }^{21} \mathrm{Z}$ informacji znajdującej się w kościele św. Piotra w Malakce. 
1795-1818. Było to związane z przejęciem Holandii przez rewolucyjną, a potem napoleońską Francję. Ostatecznie po kilku latach na mocy traktatu londyńskiego z 1824 r. cały półwysep przeszedł we władanie Anglików. Ich rządy trwały nieprzerwanie do 1942 r. Po drugiej wojnie światowej Malakka znajdowała się w składzie Strait Settlements, potem Związku Malajskiego, a następnie Federacji Malajów. Wszystkie te twory państwowe podlegały Zjednoczonemu Królestwu aż do momentu uzyskania przez Malezję niepodległości w $1957 \mathrm{r}$.

Okres panowania brytyjskiego rozpoczął się od rozebrania większości fortyfikacji. Miasto nie miało już tak dużego znaczenia, a od 1819 r. wszystkie inwestycje skupiały się na rozwoju nowego portu i miasta-Singapuru. Pod koniec XIX stulecia dodatkowym "rywalem” stało się Kuala Lumpur, pełniące rolę stolicy Federacji Stanów Malajskich. Znajdująca się pomiędzy tymi dwoma miastami Malakka straciła na znaczeniu i stała się niewielkim, prowincjonalnym ośrodkiem.

Poza kilkoma budynkami rządowymi (urzędu celnego), magazynami portowymi oraz kilkudziesięcioma willami - bungalowami okres brytyjski nie pozostawił po sobie ciekawszych zabytków architektury. Ujednolicona została zabu-

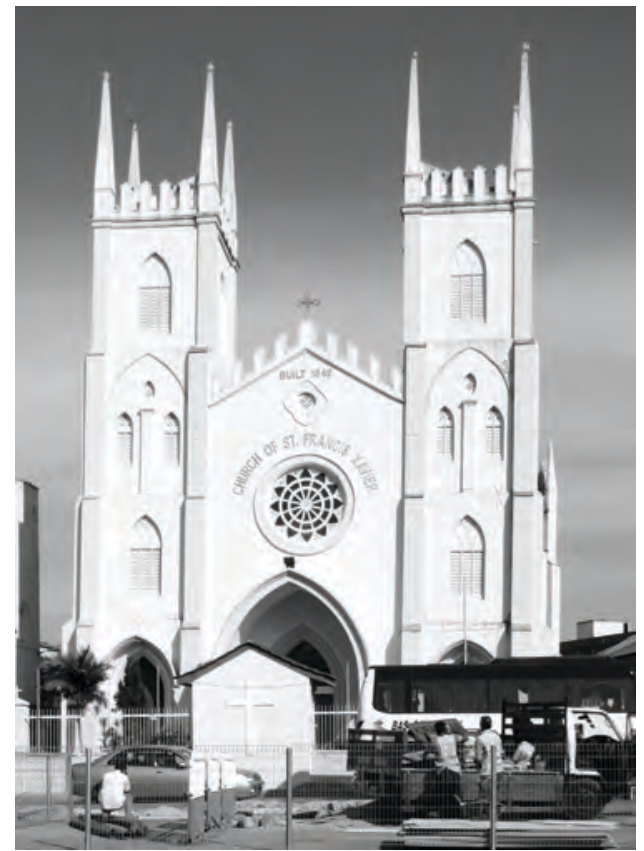

Ryc. 56. Kościół św. Franciszka Ksawerego, Malakka, 2014 dowa ulic w śródmieściu. Tworzyły je niewielkie domy z podcieniami - podobne do tych, które powstawały w tubylczych dzielnicach Singapuru czy innych miast regionu. Najbardziej widoczną w pejzażu miasta budowlą stał się kościół św. Franciszka Ksawerego, zbudowany w 1849 r. skutkiem starań francuskiego misjonarza Paula Fabre'a. Świątynia uzyskała formy mocno uproszczonego neogotyku ze skromną dekoracją rzeźbiarską ${ }^{22}$.

Malakka szczęśliwie uniknęła zniszczeń wojennych, ominęła ją także agresywna modernizacja ostatnich kilku dekad, charakterystyczna dla wielu azjatyckich miast. Dzięki temu wysoka zabudowa została umieszczona poza centrum historycznym, które w znacznej mierze zachowało

\footnotetext{
${ }^{22}$ Por. hasło „Malacca”, http://en.wikipedia.org/wiki/Malacca (dostęp: 06.09.2014).
} 
swój charakter. Dawne europejskie budynki nie zostały po odzyskaniu niepodległości zniszczone ani zdewastowane, jak zdarzało się często w byłych koloniach. Być może jedną z przyczyn był fakt, że ostatni panujący, Brytyjczycy, byli oceniani przez nowe władze malezyjskie jako ważni sprzymierzeńcy w wojnie z komunistyczną partyzantką, którzy po pokonaniu tejże, pokojowo przekazali władzę. Do dziś w Malakce, Georgetown, Kuala Lumpur i innych miastach istnieją zadbane dzielnice kolonialne, a ich zabudowa podlega opiece konserwatorskiej. Obok Galle na Sri Lance jest to także jeden z najlepiej zachowanych kompleksów holenderskiej, kolonialnej zabudowy - zachowała się ona w dużo lepszym stanie i w większej ilości niż w silnie przebudowanej i w znacznej mierze zniszczonej Dżakarcie.

Malakka jest swego rodzaju żywym miastem-skansenem z odrestaurowaną architekturą i licznymi muzeami, gdzie prezentowane są pamiątki z przeszłości i podkreślana jest jej europejskość. W początkach XXI w. przeprowadzono liczne prace wykopaliskowe, które odsłoniły m.in. przebieg dawnych murów obronnych. Relikty tychże zostały w wielu miejscach zabezpieczone i wraz z tablicami informacyjnymi stanowią część historycznego szlaku turystycznego. W 2003 r. odsłonięto część dawnego bastionu Santiago, a w 2006 r. odkryto fundamenty bastionu Middelburg. Dwa lata później otwarto i udostępniono do zwiedzania jego rekonstrukcję ${ }^{23}$. Obiekt ten, podobnie jak i „podmiejski” fort św. Jana (Bukit Senjuang), to w znacznej mierze kreacja, której odtworzenie (stworzenie) jest dość kontrowersyjne z punktu widzenia konserwatora czy historyka sztuki. Niewątpliwie jednak, wraz ze wspomnianymi już, dobrze opracowanymi tablicami informacyjnymi, atrapy te są w stanie przybliżyć obraz dawnej Malakki licznym zwiedzającym.

Dzisiejsza Malakka to miasto wielu zabytków kolonialnych. Stanowią one jeden z bardziej charakterystycznych elementów w tamtejszym krajobrazie. Narzucone jako obce, związane z odmienną kulturą, tradycją, religią, przyniesione przez zdobywców stały się wartością historyczną przyciągającą turystów. Malakka należy dziś do lepiej funkcjonujących ośrodków miejskich na Dalekim Wschodzie i nie odżegnuje się od niejednokrotnie trudnego i skomplikowanego kolonialnego dziedzictwa. Konserwując zabytki kultury materialnej, zachowuje swój charakter miasta wielokulturowego, które przed wiekami było jednym z ważniejszych portów na mapie świata.

${ }^{23}$ Por. hasło „A Famosa”, http://en.wikipedia.org/wiki/A_Famosa (dostęp: 06.09.2014); Z. Majid, op. cit. 


\section{BIBLIOGRAFIA}

\section{OPRACOWANIA DRUKOWANE}

Boxer C.R., Morskie Imperium Holandii 1600-1800, Gdańsk 1980.

Dias P., Historia Da Arte Portuguesa No Mundo (1415-1822). O Espaco do Indico, Navarra 1998. Hollis Ch., Historia jezuitów, Warszawa 1974.

Kip Lin L., The Singapore House 1819-1942, Singapore 1995.

Majid Z., Bastion Middelburgh, bmw., bdw.

Plattner F. A., Gdy Europa szukała Azji, Kraków 1975.

Wank-Nolasco L. R., History of Macau, Macau 1998.

Wyczański A., Historia powszechna. Wiek XVI, Warszawa 1999.

\section{ŹRÓDŁA INTERNETOWE}

„A Famosa”, http://en.wikipedia.org/wiki/A_Famosa (dostęp: 01.09.2014).

"Christ Church", http://en.wikipedia.org/wiki/Christ_Church_Malacca (dostęp: 01.09.2014).

„Dutch Malacca”, http://en.wikipedia.org/wiki/Dutch_Malacca (dostęp: 01.09.2014).

„Malacca sultanate”, http://en.wikipedia.org/wiki/Malacca_sultanate (dostęp: 01.09.2014).

Obiekty z listy światowego dziedzictwa UNESCO, [online], http://pl.wikipedia.org/wiki/

Obiekty_z_listy_dziedzictwa_UNESCO_w_Azji\#Malezja_.284.29 (dostęp: 01.09.2014).

„Parameswara sultan”, http://e.wikipedia.org/wiki/Parameswara_sultan (dostęp: 01.09.2014).

„Portugeuse Malacca”, http://en.wikipedia.org/wiki/Portuguese_Malacca (dostęp: 01.09.2014).

\section{SUMMARY}

\section{European Architecture in Malacca}

The city of Malacca was founded ca. 1400 by Iskander Shah, but it belonged to Malays only for a century. From 1511 till 1957 this town was in possession of Europeans. As one of the main ports in the Far East it played a huge role in the international trade - especially in the $16^{\text {th }}$ and $17^{\text {th }}$ centuries. There were three periods of European architecture in Malacca: Portuguese (1511-1641), Dutch (1641-1825) and British (1825-1957). In this text we show some examples from the first European foundations till the $20^{\text {th }}$ century, from the first fortifications and Catholic churches to English bungalows. Nowadays the city is one of the best examples of colonial heritage in Asia (UNESCO World Heritage List from 2008). Also, the recent excavations of fortifications, reconstructions of some bastions, creation of museums dedicated to its foreign pasts, show how this heritage is appreciated by local government. 